\title{
Ammonia CI engine aftertreatment systems design and flow simulation
}

ARTICLE INFO

Received: 15 July 2021

Revised: 6 August 2021

Accepted: 18 October 2021

Available online: 22 November 2021
Investigation of exhaust emissions and ammonia flow behavior in the exhaust system incorporating with Selective Catalytic Reduction (SCR) unit is discussed. An aftertreatment system is designed to work without additional urea injection. This study is focused on obtaining optimal parameters for catalysis. Its effectiveness is considered as a function of basic parameters of exhaust gases mixture and SCR material characteristics. A $3 D$ geometry of SCR with porous volume has been simulated using Ansys Fluent. Moreover, a 1D model of ammonia dual-fuel CI engine has been obtained. Results were focused on obtaining local temperature, velocity, and exhaust gases composition to predict optimal probes placement, pipes insulation parameters, and characteristic dimensions.

Key words: ammonia, SCR, compression ignition engine, test rig, emissions

This is an open access article under the CC BY license (http://creativecommons.org/licenses/BY/4.0/)

\section{Introduction}

Ammonia can be used with diesel fuel or any other fuels in dual-fuel model, notably decreasing carbon and, in specific cases, also nitrogen-based emissions. Nevertheless, research on ammonia dual-fuel engines is still in early stage progressing, and there are only a few papers regarding ammonia as the primary fuel for ICE. Grannell et al. [1] examined mixtures of ammonia in gas phase and gasoline in a spark ignition (SI) cooperative fuel research engine. Different ammonia/gasoline ratios were utilized in knock free condition. Their test results revealed that performance of engine with a mixture of $70 \%$ ammonia and $30 \%$ gasoline by mass could be applied. Even higher ammonia to gasoline ratio was possible for supercharged operation. Reiter et al. [2] investigated a compression-ignition engine's combustion and emissions characteristics using a dual-fuel method with ammonia and diesel oil. Gaseous ammonia was sprayed into the intake system, and diesel oil was injected inside the cylinder to ignite the mixture. They examined several ammonia/diesel ratios with a small mass of diesel fuel and different mass flow of ammonia. The approved operating range was to utilize 40-60\% energy provided by diesel fuel mixture with $60-40 \%$ energy from the ammonia. Moreover, their measurements show that increasing the quantity of ammonia will result in longer ignition delays. Besides, using the dual-fuel method, $\mathrm{CO}$ and hydrocarbons emissions were higher than using small dose of diesel fuel to obtain the same output power. In contrast, $\mathrm{NO}_{\mathrm{x}}$ emissions were different with various ammonia/diesel mass flow. NO emission for $40 \%$ ammonia dualfuel engine is lower than $100 \%$ diesel engine, but in $60 \%$ ammonia case, NO emission increased significantly. Their other work [3] proved that ammonia could be potentially used as an engine fuel because it has the same energy content per unit mass like a stoichiometric mixture of fossil fuels. Additionally, the results illustrated that different ammonia-diesel fuel ratios could be used to obtain the same engine torque. Furthermore, ammonia can replace as much as $95 \%$ of total energy with successful engine performance.
Good fuel economy can be achieved when ammonia is applied to supply $40-80 \%$ of the total input energy. Salek et al. [4] numerically studied the effects of port injection of ammonia on performance of engine and emissions at various range of engine speeds for an ethanol/gasoline dual-fuel SI engine. They used AVL BOOST for the numerical investigation, which validated with their experiment data. Results reveal that $10 \%$ port injection of ammonia decreases the engine cylinder temperature by $50 \mathrm{~K}$, which resulted in a remarkable diminution in $\mathrm{NO}_{\mathrm{x}}$ emissions by $50 \%$ across the various engine speed. However, it imposes some unfavorable impacts on engine equivalent $\mathrm{BSFC}, \mathrm{CO}$, and $\mathrm{HC}$ emissions, increasing them by $3 \%, 30 \%$, and $21 \%$, respectively. Additionally, the required low octane number of fuel to prevent knock is reduced by $10 \%$ ammonia port injection, which proves that the ammonia port injection can undoubtedly impact the engine knock. Besides, port injection of ammonia raised $2 \%$ of the exhaust energy loss.

Appropriate control of combustion may reduce the amount of $\mathrm{NO}_{\mathrm{x}}$ produced and perhaps they will not exceed the values typically occurring in diesel engines [5]. That amount of $\mathrm{NO}_{\mathrm{x}}$ is still harmful to humans and contributes to greenhouse effect. However, DeNOx catalysts are standard element of exhaust systems and are specifically designed to reduce that pollutant. Commercial application of such catalysts begun in Japan in 1977 [6] for reducing harmful nitric oxides from exhaust gases. Some investigation was performed for obtaining optimal operating value [7] in automotive applications - both for flow profiles and temperatures distributions. Different technologies are used depending on planned application, as different catalysts offer ranges of activation energy and catalysis effectiveness. The reduction of $\mathrm{NO}$ to harmless $\mathrm{N}_{2}$ occurs in presence of reductant. Injected reductant is commonly urea or another hydrogen carrier, but ammonia is sufficient for that reaction. The $\mathrm{NH}_{3}$ concentration uniformity across the catalyst cross section has positive impact on catalysis reaction [8]. Urea-SCR is generally effective method of reducing $\mathrm{NO}_{\mathrm{x}}$ but has three main limitations [9]: size, temperature and cell 
density. Size and cell density are treated in this study as given: resultant of space available in agriculture vehicle/car and producers limitation. Low temperature operation is problematic because of incomplete thermal decomposition into $\mathrm{NH}_{3}$ and formation and decomposition of residues. First factor reduces conversion rate and the second may lead to deposits blocking SCR and reducing its lifetime [10]. A range of metal-based catalysts are considered [11] but in all cases their conversion rate in flows below $150^{\circ} \mathrm{C}$ is limited and in case of urea close to impossible. One such a type, especially useful in automotive industry due to its low operating temperature, such as $523-573 \mathrm{~K}$ range, are $\mathrm{V}_{2} \mathrm{O}_{5}$ covered catalysts [12]. Reactions in SCR are gas-solid multi-phase catalytic reactions [13] and reaction kinetics, temperature and gases composition affect them greatly. The literature provides wide spectrum of different reaction mechanisms to choose from, that are appropriate to specific cases. Obviously, crucial selection sieve is also reaction mechanism adapted. Depending on materials used, residence time (resultant of length and flow velocity) and temperature different mechanism becomes more pronounced. Among those Eley-Rideal of surface-only reaction, 2 cyclecatalysis Topsøe [13] catalysis model for standard reaction time, Ciardelli [14] or Nova [15] for low temperature $\mathrm{NO}_{\mathrm{x}}$ reduction and Grossal for $\mathrm{NH}_{4} \mathrm{NO}_{3}$ formation are commonly used. Calculations run those mechanisms in parallel [13] or even coupled as in Mars-Van Krevelen model [15] when process is heterogynous or one of them when it's possible to select one homogenous leading mechanism.

The goal of this research is to obtain a method of optimization of $\mathrm{NH}_{3}-\mathrm{SCR}$ process with respect to gases composition, temperature and mass flow for a given catalyzer type. Method should be computationally cost-effective as numerical optimization would require to run it multiple times for different variants, including multiple gas compositions. If such a method is obtained reduced model for real time application could be considered.

In this work measurement of fuel consumption, exhaust gases composition and temperature against the load is performed. Then collected data is fed into numerical models: 1D model of engine operation and 3D CFD model of temperature and velocity distribution. Ammonia port injection engine are modeled by 1D approach. The 3D CFD model will utilize two important simplifications: premixed mixture of exhaust gases and porous zone model.

\section{Experimental Setup}

\subsection{Test rig and laboratory setup}

The test rig setup of exhaust system had to be designed so it can be incorporated into stationary test rig and operating agricultural vehicle. This requires not only proper type of probes selected for their respective tasks but narrowly constrained positioning, too. The entirety of laboratory test bench had to fit in $780 \times 700 \times 1850$ boundary box to maintain its maneuverability and to access all planned operating sites. It could not exceed $250 \mathrm{~kg}$ and should be modular to offer reassembly possibility.

Despite of its experimental character exhaust system has to be carefully insulated due to operating right next to ammonia fueling line (green pipe in the Fig. 1). This combined with limited space resulted in interest of calculating heat losses of gases before entering SCR unit and their desired temperature for optimal operation.
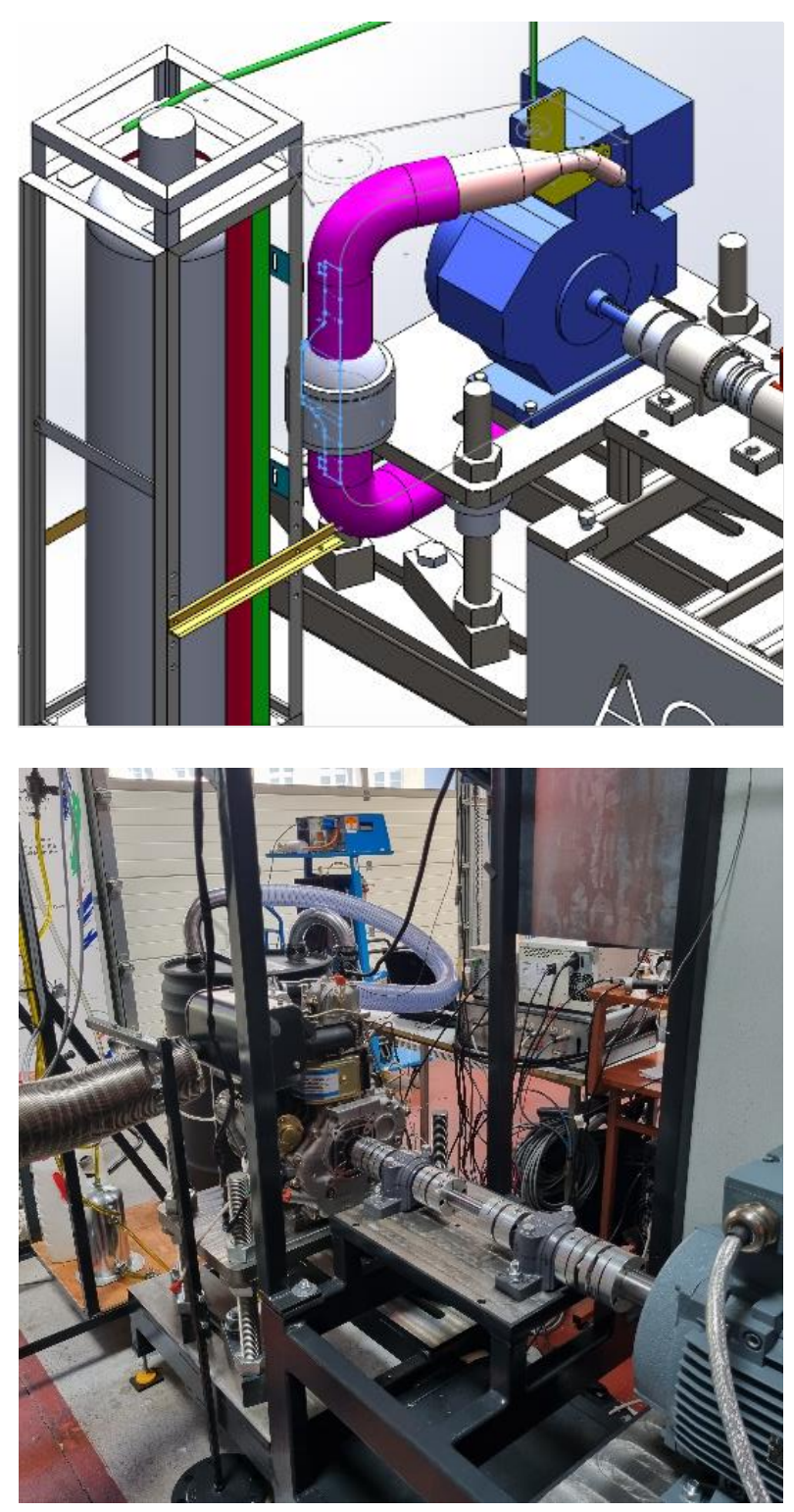

Fig. 1. Laboratory setup of design stage test rig (top) and manufactured test rig (bottom)

The measurement bases were as follows: axis of engine shaft, front plate of engine (the beginning of shaft) and mounting (bottom) plate. Those are not subdued to any (planned) changes and cooperating parts can be easily accustomed.

In case of engine shaft entire construction of laboratory stand supports easy and precise setup of angle with four degrees of freedom, and additional tilt of the table as a fifth (albeit not as precise as the four others). There are two possibilities of movement along $\mathrm{X}$ (along the shaft) and $\mathrm{Y}$ (perpendicular to shaft, parallel to table) axes: major movement realized by sliding of the dices ( 1 in Fig. 2) secured in position with screws (2 in Fig. 2) or minor movement allowed by slots ( 3 in Fig. 2) in engines bottom plate. 


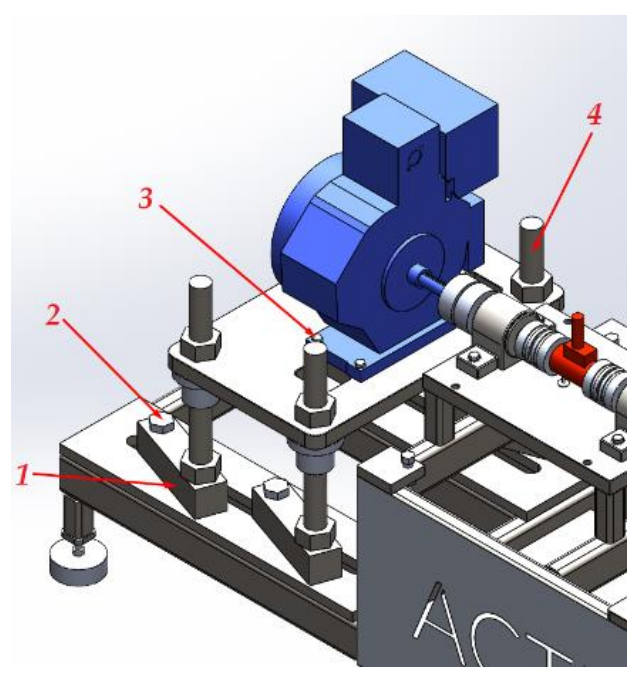

Fig. 2. Parts enabling positioning of the engine

Main movement in $\mathrm{Z}$ axis is resolved by four metric screws (4 in Fig. 2). They are also responsible for aforementioned tilt - or rotation with respect to either $\mathrm{X}$ or $\mathrm{Y}$ axis - if the screwing will not be uniform. Rotation with respect to $\mathrm{Z}$ axis is resolved by movement of the support dices or slots, exactly same as in the case of movement in $\mathrm{X}$ direction.

Utilizing two gas analyzers with different measuring range (this is crucial in case of $\mathrm{CO}$ limit) performance of agricultural vehicle with constant rollers' RPM under set of loads were tested. Tests were performed for a range of different operating cases: ignition and cold engine, subsequent tests during vehicle operation and finished when black smoke limit was reached. The fuel flow was of interest as well but it was measured with build-in sensors of vehicle.

\subsection{Experimental setup and SCR structure}

In this study monolithic ceramic honeycomb SCR with vanadium oxidate $\left(\mathrm{V}_{2} \mathrm{O}_{5}\right)$ coating on anatase and silica $\left(\mathrm{TiO}_{2}\right.$ and $\left.\mathrm{SiO}_{2}\right)$ is investigated. The 3D model was reverse engineered from commercial SCR and its main dimensions and properties of monolith are displayed in Table 1.

The SCR is installed in laboratory exhaust line as shown in the Fig. 3 and fed exhaust gases from Lifan C186F engine operating with preset conditions. Manufacturers information about engine are included in Table 2. Temperature, pressure and composition of exhaust gases are measured in sub sequent points of the exhaust. Looking from the exhaust inlet, as displayed in the Fig. 3 there is temperature $1 \mathrm{a}$ and lambda $2 \mathrm{a}$ sensors, reference pressure $4 \mathrm{a}$ and temperature $1 \mathrm{~b}$ before the monolith, differential pressure $4 \mathrm{~b}$ before and $4 \mathrm{c}$ after the monolith and gases composition $5 \mathrm{a}$ before and $5 \mathrm{~b}$ after the SCR. In the figures are also displayed nests $3 \mathrm{a}$ and $3 \mathrm{~b}$ for real time $\mathrm{NO}_{\mathrm{x}}$ concentration and $6 \mathrm{a}$ and $6 \mathrm{~b}$ for FTIR measurements but they were not used in this study. The internal geometry of the whole exhaust system is simplified for CFD modelling - the probes elements, small wedges and fillets were omitted due to their minuscule impact on fluid flow. The length of exhaust after the SCR could be reduced as well, but long pipe generally increases stability of solution reducing backflow problems.

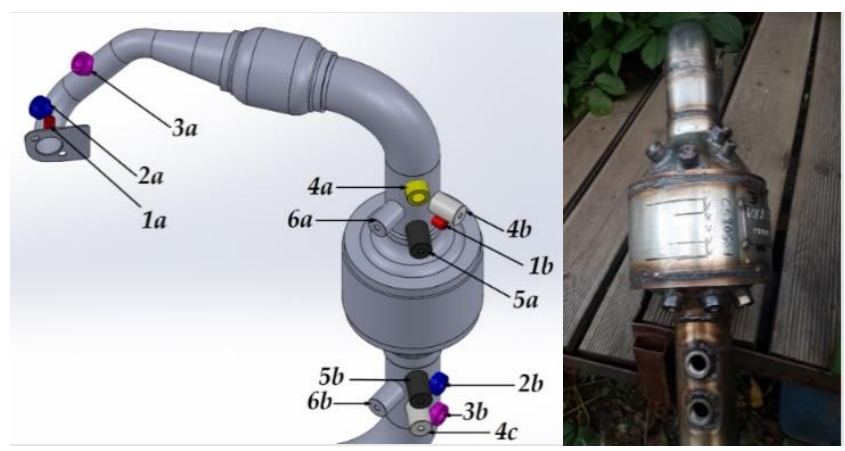

Fig. 3. Probes positions on exhaust piping modeled and final application

Table 1. SCR unit dimension and properties

\begin{tabular}{|l|c|c|}
\hline Parameter & Unit & Value \\
\hline Honeycomb type & - & Square opening \\
\hline Coating material & - & $\mathrm{TiO}_{2}-\mathrm{SiO}_{2}$ \\
\hline Catalyst material & - & $\mathrm{V}_{2} \mathrm{O}_{5}$ \\
\hline Monolith diameter & $\mathrm{mm}$ & 143.764 \\
\hline Monolith length & $\mathrm{mm}$ & 76.2 \\
\hline Cell density & $1 / \mathrm{cm}^{2}$ & 47 \\
\hline Porosity & - & 0.48 \\
\hline
\end{tabular}

Table 2. Lifan C186F important values

\begin{tabular}{|l|c|c|}
\hline Parameter & Unit & Value \\
\hline Engine type & - & $\begin{array}{c}\text { 4-stroke, OHV, single } \\
\text { cylinder, forced air }\end{array}$ \\
\hline Bore $\times$ Stroke & $\mathrm{mm} \times \mathrm{mm}$ & $86 \times 70$ \\
\hline Displacement & $\mathrm{cm}^{3}$ & 406 \\
\hline Compression ratio & - & $19: 1$ \\
\hline Maximum speed & $\mathrm{rpm}$ & 3600 \\
\hline Maximum power & $\mathrm{kW}$ & 6.8 \\
\hline
\end{tabular}

Differences between modeling of $\mathrm{NO}_{\mathrm{x}}$ conversion in $\mathrm{Se}$ lective Catalytic Reduction units are stark. The approaches differ by style of geometry modeling: full geometry mesh modeling [7], single channel modeling [13] and porous zone modeling [16]. Those methods are further refined by adaptation of cyclic or symmetry boundary conditions allowing for meshing of just a fraction of geometry thus reducing computational complexity. Their limitations are derived directly from simplifications: full geometry mesh modeling offers least of them at the cost of mesh size or quality, single channel modeling ignores radial differences between channels, porous zone when exact formation zones are of no importance.

\section{Numerical models}

\subsection{One dimensional modeling engine performance}

The 1D model of single cylinder diesel engine is shown in Fig. 4. It was simulated using AVL BOOST software. This model includes the engine (E1), single cylinder (C1), Inlet (SB1) and outlet (SB2) boundary conditions, measurement points 1 and 2 (MP1, MP2), and the lines representing pipes. For this model data for setting cylinder covers the basic dimensions of the cylinder like bore, stroke, compression ratio, piston pin offset, plus information on the 
combustion characteristics, heat transfer, scavenging process and valve specifications for the attached pipes. Therefore, the cylinder dimensions and inlet and exhaust valves lift profiles from measurements of the engine have been used to set the 1D model. As initialization, the cylinder conditions, pressure, temperature, and gas composition at the end of the high pressure at exhaust valve opening were set. Furthermore, the initial conditions for the calculation of the cylinder have been specified.

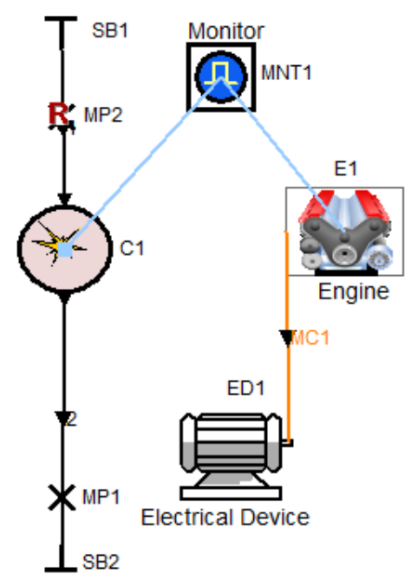

Fig. 4. One dimensional model of the engine in the AVL BOOST

The heat release rate in the cylinder was modeled by Vibe function. Vibe function is often used to approximate the heat release characteristics of the engine. Figure 5 illustrates the approximation of a heat release profile of the diesel engine by a Vibe function for different values of ' $m$ ' shape parameter $(0.4,0.6,0.8$, and 1$)$. Shape parameter indicates how combustion and heat release are fast. For different values of ' $m$ ' the Vibe diagram and burned fuel mass fraction are calculated and presented in this figure in order to obtain and validate numerical results with experimental data. However, for accurate modeling of the double peak heat release in the cylinder, since there are two peaks in the heat release diagram, the first peak due to premixed burning and the second peak due to diffusion combustion. Therefore, two Vibe functions will be specified for this study modeling. In this work, port injection of ammonia and premixed ammonia air mixture in the cylinder require to model premixed combustion, hence, premixed combustion are modeled by Vibe1. The superposition of two Vibe (Double Vibe) functions is utilized to predict the heat release rate of a diesel engine with direct injection more precisely. So, two Vibe functions are specified, the first Eq. 1 is used to model the premixed combustion and the second Eq. 2 is used to model diffusion combustion. Therefore, the combustion process in the cylinder can be modeled by the following equations, known as Vibes function:

$$
\begin{gathered}
\mathrm{x}_{1}=\sigma_{\mathrm{g}}\left(1-\mathrm{e}^{-\mathrm{C}\left(\Phi_{1} / \emptyset_{\mathrm{z} 1}\right)^{\mathrm{m}_{1}+1}}\right) \\
\mathrm{x}_{2}=\left(1-\sigma_{\mathrm{g}}\right)\left(1-\mathrm{e}^{-\mathrm{C}\left(\boldsymbol{\emptyset}_{2} / \emptyset_{\mathrm{z} 2}\right) \mathrm{m}_{2}+1}\right)
\end{gathered}
$$

Double Vibe function is expressed as the sum of the first and the second part of the Vibe function:

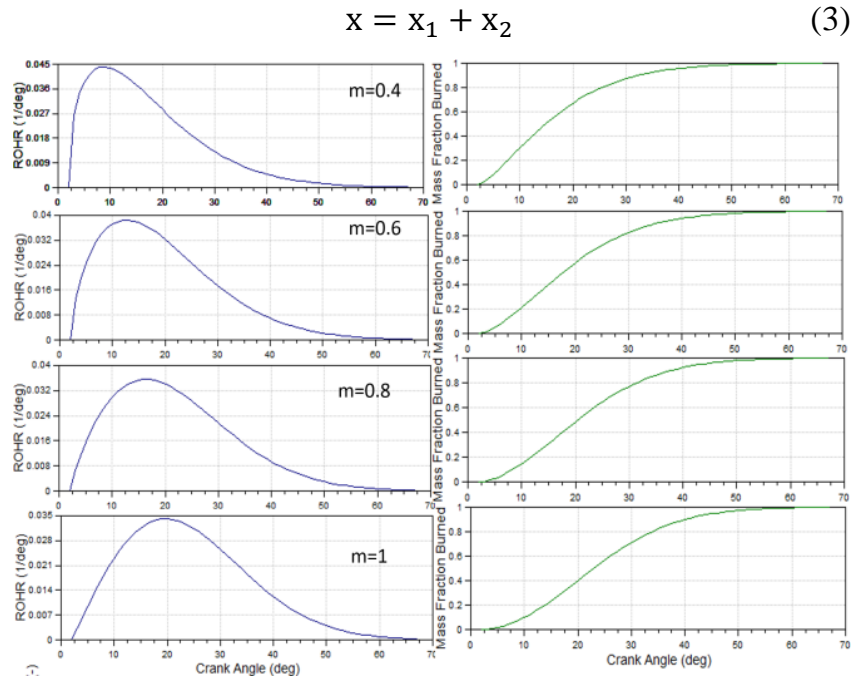

Fig. 5. First Vibe curve to model combustion and heat release in the cylinder, and influence of $\mathrm{m}$ (shape parameter)

\subsection{D model of exhaust system with porous zone}

Since detailed modelling of used SCR would require meshing total of 7500 channels with hydraulic diameter of around $1 \mathrm{~mm}^{2}$ porous zone approach was chosen. Porous zone is modeled by introducing momentum sink into the standard fluid flow equations. In some approaches porous zone model can approximate turbulence, but in these calculations, flow was considered laminar due to very low hydraulic diameter of relatively long channels. To utilize this approach source term $\mathrm{Si}$ has to be modelled. Following experimental results from $[17,18]$ it can be modelled using Darcy-Forchheimer equation:

$$
\mathrm{S}_{\mathrm{i}}=\frac{\Delta \mathrm{p}}{\Delta \mathrm{L}_{\mathrm{i}}}=-\left(\frac{\mu}{\alpha} \mathrm{v}_{\mathrm{i}}+\mathrm{C}_{2} \frac{1}{2} \rho \mathrm{v}_{\mathrm{i}}^{2}\right)
$$

Following pressure drop obtained from experiments [17] on similar device and operating conditions:

$$
\Delta \mathrm{p}=\mathrm{av}_{\mathrm{i}}^{2}+\mathrm{bv}_{\mathrm{i}}
$$

Comparing equations 4 and 5 viscous and inertial resistance can be obtained as follows:

$$
\begin{aligned}
& \frac{1}{\alpha}=\frac{b}{\mu \Delta \mathrm{L}_{\mathrm{i}}} \\
& \mathrm{C}_{2}=\frac{2 \mathrm{a}}{\rho \Delta \mathrm{L}_{\mathrm{i}}}
\end{aligned}
$$

Taking those assumptions for porous zone geometry model was prepared and meshed as seen in the Fig. 6. The volumetric fractions of subsequent species were taken from measurement results of exhaust gases as seen in the Table 3 and gaseous ammonia was added to the mixture. The viscosity was calculated.

Calculations were run in two segments: first of "cold flow" without heat exchange and second with heat exchange enabled. This method was used to decrease computing time and stabilize the solution. With used mesh and computing power first set of calculations was converged after 300 iterations. After adding heat exchange through walls, the residual values became stable after additional 200 iterations. In both cases all residuals stabilized below 0.00001 with exception of 
continuity residual that maintained at 0.001 . For modeling mixture ideal gases with mixing law was used, and respective percentages are in Table 3.

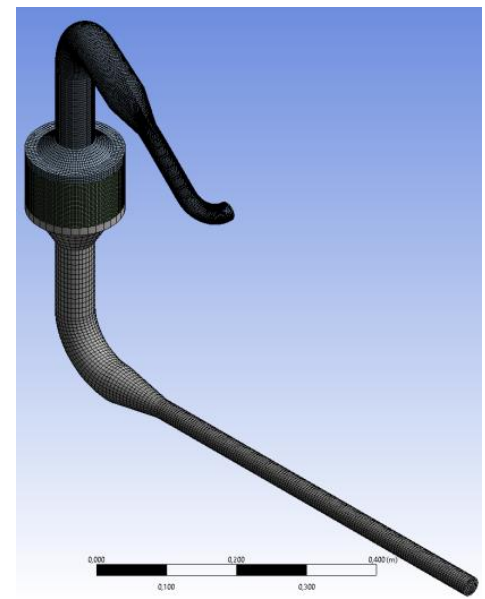

Fig. 6. Finite element mesh consisting of 344672 elements

Table 3. Volumetric fractions of species in exhaust gases with added $\mathrm{NH}_{3}$

\begin{tabular}{|l|c|c|}
\hline Species & Unit & Value \\
\hline $\mathrm{CO}$ & $\%$ vol & 0.327 \\
\hline $\mathrm{CO}_{2}$ & $\%$ vol & 9.22 \\
\hline $\mathrm{O}_{2}$ & $\%$ vol & 8.52 \\
\hline $\mathrm{NO}$ & $\%$ vol & 0.1167 \\
\hline $\mathrm{NO}_{2}$ & $\%$ vol & 0.1202 \\
\hline $\mathrm{NH}_{3}$ & $\%$ vol & 0.0069 \\
\hline $\mathrm{N}_{2}$ & $\%$ vol & 81 \\
\hline
\end{tabular}

\section{Results and discussion}

\subsection{Effects of ammonia port injection}

The numerical results of the one-dimensional modeling of ammonia port injection have been obtained. The double Vibe combustion model has a good prediction of heat release compering with experimental data. The diagram of the heat release rate of the engine is shown in Fig. 7, the first peak is due to premixed combustion, and the second one is due to diffusion combustion.

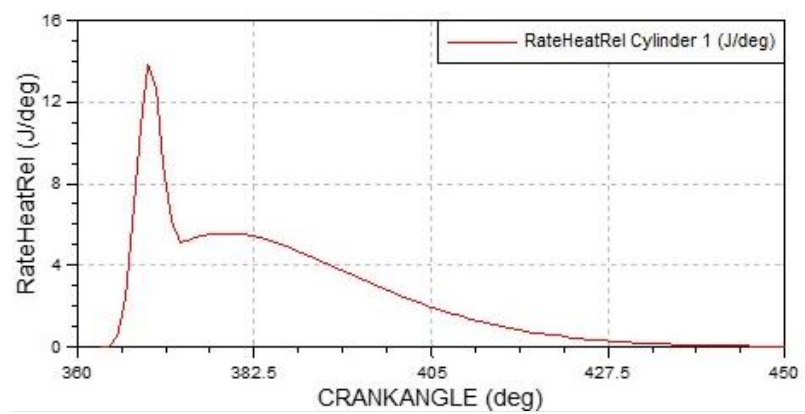

Fig. 7. Heat release rate modeled by double Vibe function for Lifan engine

Figure 8 shows the mass fraction of the selected species, the initial composition inside cylinder like $\mathrm{CO}_{2}, \mathrm{H}_{2} \mathrm{O}$, and $\mathrm{O}_{2}$ can be seen at $0 \mathrm{CA}$. The mass fraction of gaseous ammonia is increased during the intake stroke and then by spraying diesel and starting combustion it decreases.

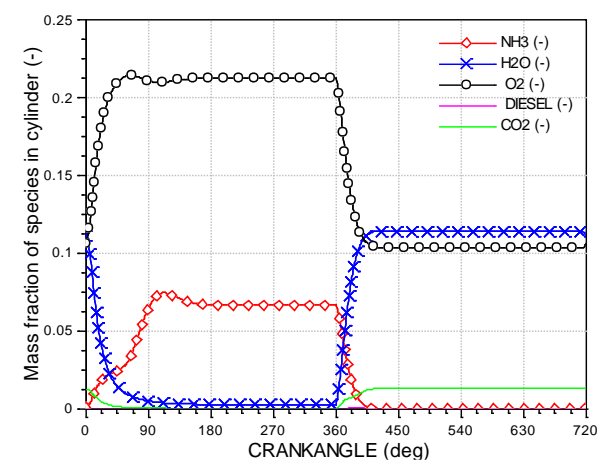

Fig. 8. Mass fraction of in-cylinder species

In-cylinder temperature and pressure diagrams are represented in Fig. 9, the numerically predicted pressure and temperature curves was calculated based on the measured in cylinder pressure. The temperature and pressure figures similar behavior to the only diesel one. The input energy supplied by ammonia for the ammonia port injection engine is equal to maximum power of the engine fueled by only diesel. $85 \%$ of input energy supplied by liquid ammonia port injection. Figure 10 illustrates exhaust emissions of the ammonia-fueled engine, $\mathrm{NO}$ and $\mathrm{CO}_{2}$ emissions have been measured in the steady-state condition of 4 seconds running engine. As can be seen in this figure, emission of $\mathrm{CO}_{2}$ less than $2 \%$ of exhaust gas.
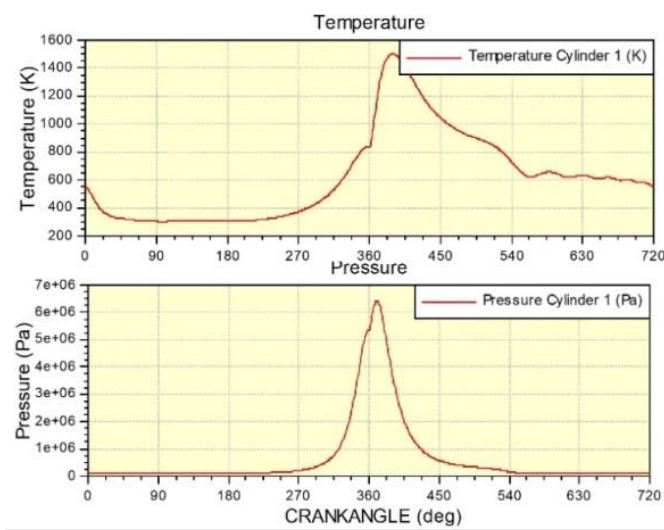

Fig. 9. In-cylinder temperature and pressure for ammonia port injection engine
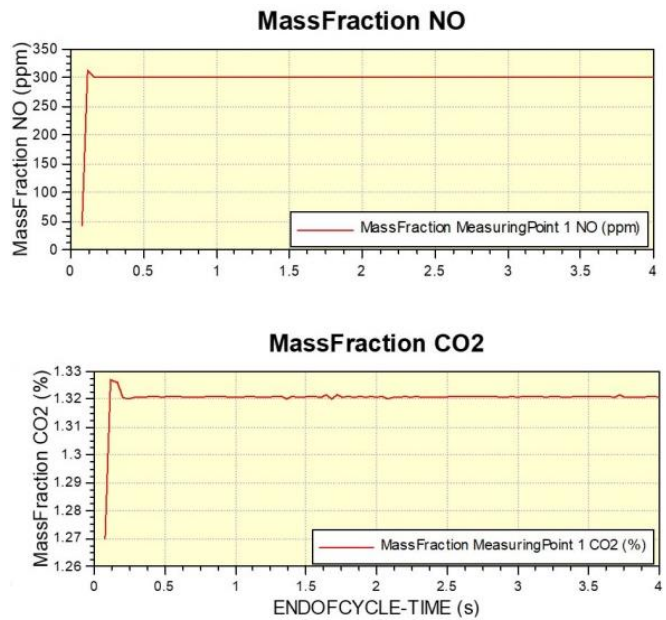

Fig. 10. Exhaust emissions of ammonia port injection in AVL BOOST 


\subsection{Effects of different loads on exhaust gases parameters}

They can be seen in the Fig. 11. During normal operation up to load of $400 \mathrm{~N}$ the measured concentration of $\mathrm{CO}$ is kept below $6000 \mathrm{ppm}$ and rises slowly symmetrically to fall of $\mathrm{O}_{2}$. Above the first analyzer measurement range at $2500 \mathrm{ppm}$, so for loads higher than $380 \mathrm{~N}$ up to $530 \mathrm{~N}$, a rapid rise can be observed from $4000 \mathrm{ppm}$ to $6500 \mathrm{ppm}$. Meanwhile the concentration of hydrocarbons and $\mathrm{NO}_{x}$ formation is on similar level as measured by first analyzer.

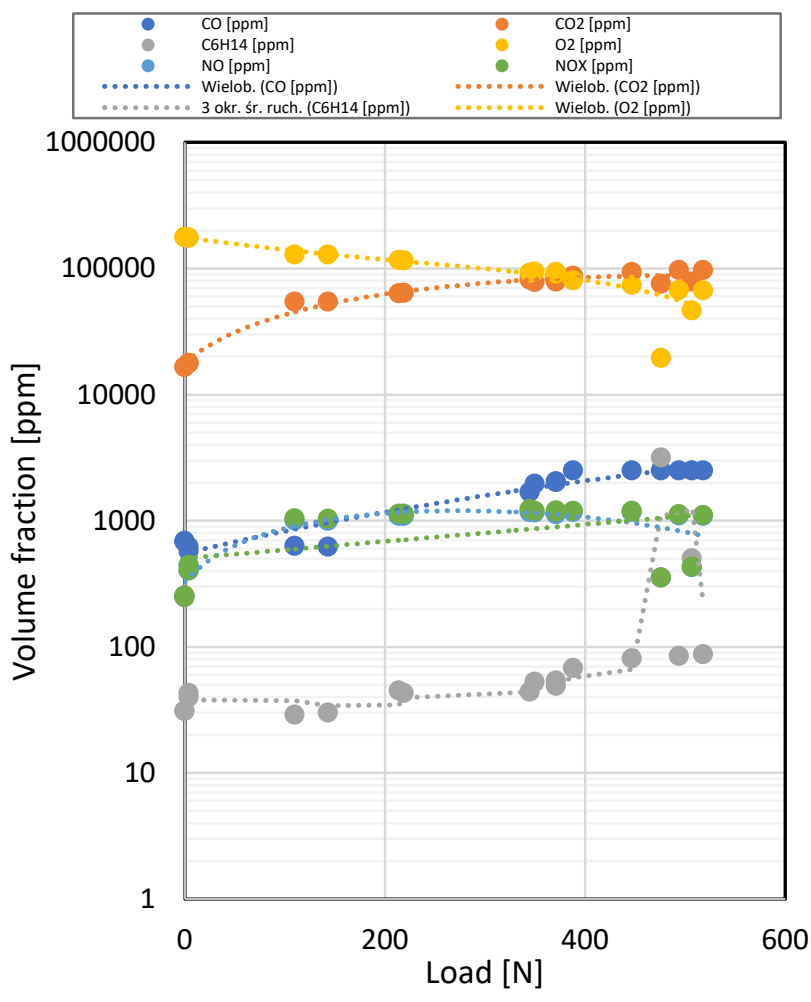

Fig. 11. Exhaust gases composition as a function of engine load during operation in $1500 \mathrm{rpm}$

Operating in $1700 \mathrm{rpm}$ with similar loads proved to be less strenuous to the engine and resulted in cleaner combustion. Black smoke limit was reached as can be noticed in the Fig. 12 for the load close to 700 N. Unburned hydrocarbons concentration is shifted and rises above $600 \mathrm{~N}$.

The rise of $\mathrm{CO}$ and $\mathrm{HC}$ concentration for a high load can be expected and is a result of reaching critical pressure in-cylinder that prohibits fuel from proper mixing and thus resulting in unburned mixture pushed off the engine with exhaust gas. For $1500 \mathrm{rpms}$ set for this test it seems that reasonable limit of load dictated by cleaner combustion is at maximum $530 \mathrm{~N}$, while $1700 \mathrm{rpm}$ can operate up to $610 \mathrm{~N}$.

Since exhaust gases temperature is one of the most important parameters for SCR proper operation, it was directly measured at the first element of inlet by thermocouple inserted in between two gaskets.

The temperature rise was proportional to increased load and measurements allowed to pick set of gas composition parameters to check the flow in the exhaust system. The set chosen for this are results for loads ranging from 300 to 400 $\mathrm{N}$, with the average temperature of $700 \mathrm{~K}$.

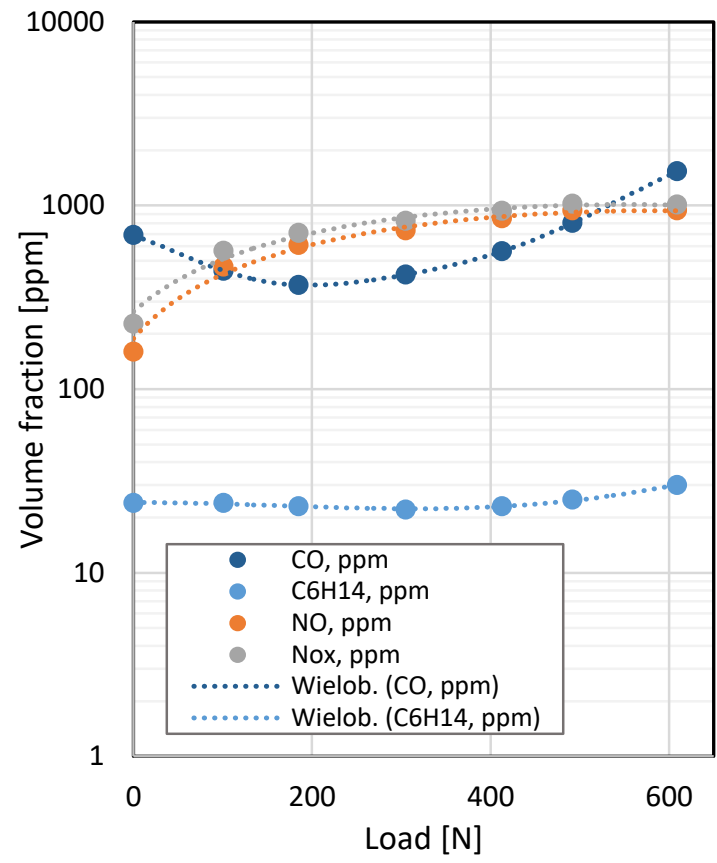

Fig. 12. Exhaust gases composition as a function of engine load during operation in $1700 \mathrm{rpm}$
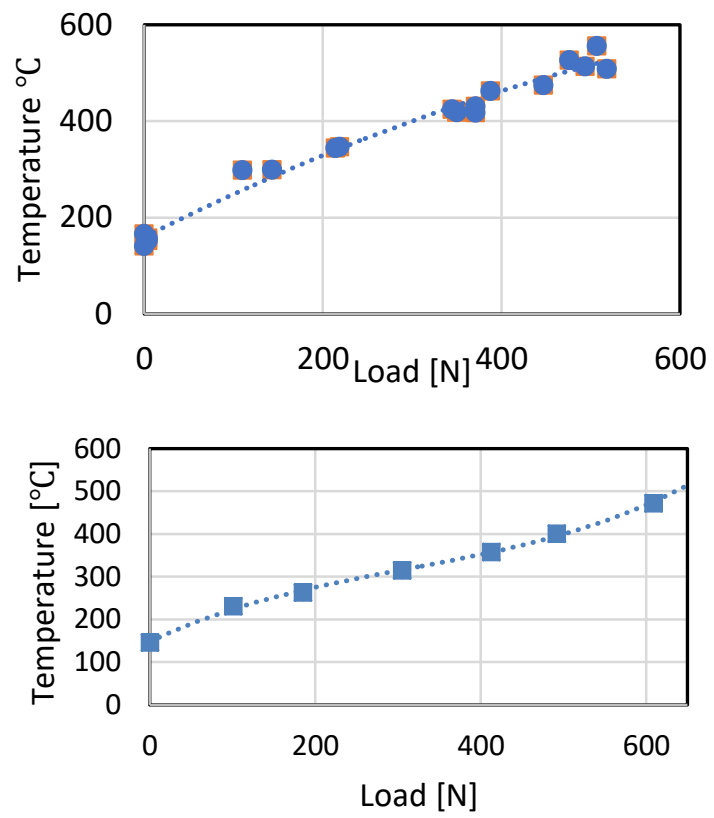

Fig. 13. Exhaust gases temperature as a function of engine load during operation in $1500 \mathrm{rpm}$ and $1700 \mathrm{rpm}$

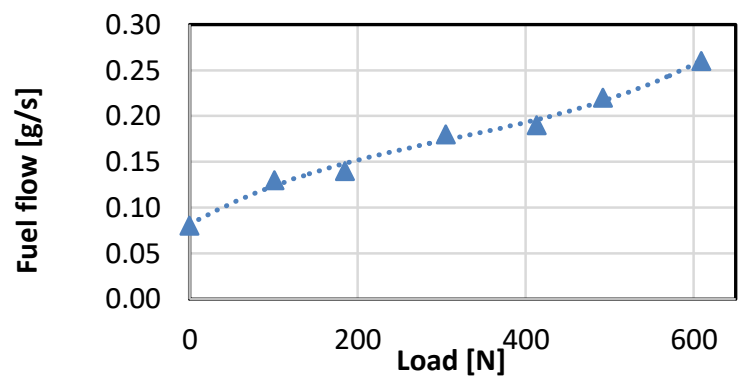

Fig. 14. Fuel flow as a function of engine load during operation in $1700 \mathrm{rpm}$ 


\subsection{Flow through porous zone}

To reliably predict and model reactions inside the SCR unit and further design exhaust system two types of results are necessary: temperature and velocity distribution. Both types of the results were 3D plotted against the exhaust shape to present estimations of exhausts gases flow velocities in Fig. 15, temperature drop along the pipe and temperature distribution in the SCR vicinity in the Fig. 16.

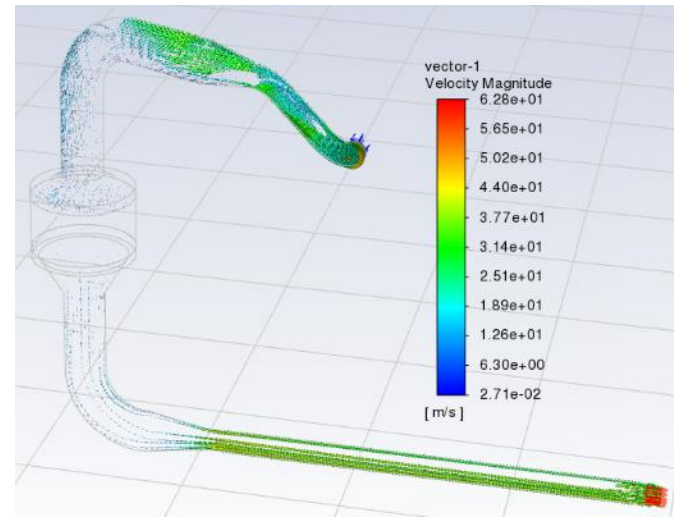

Fig. 15 . Velocity profile for $0.016 \mathrm{~kg} / \mathrm{s}$ mass flow and ambient pressure outlet

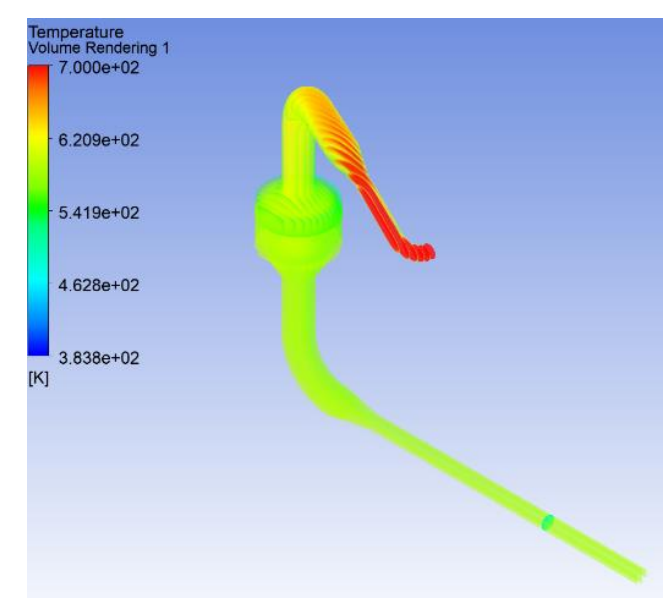

Fig. 16. Temperature distribution within the exhaust system

Substantial temperature drop that can be seen in the Fig. 16 from flow core towards outer surface of SCR proves that single channel simplification would be quite unreliable way of predicting reactions within it. Since porous zone model generally does not support non-uniform distribution of temperature between fluid and solid parts the only possibil- ity to precisely capture it would be direct 3D model of honeycomb monolith.

Intense cooling in first element of piping, resultant of relatively high speed and temperature of fluid, is also undesirable effect that needs to be taken into account in redesign process. In case of selected inlet temperature SCR still can operate with some efficiency despite drop, but during exhaust gases measurements way lower temperatures were observed.

\section{Summary and overall conclusions}

This study shows methods of creating input values for catalysers reactions calculations by preparing thermodynamic parameters (especially temperature and velocity distribution) of flow entering the porous zone. The results of calculations from this paper can be further used to model reaction inside the SCR monolith - perhaps with different modelling approach to capture surface reactions of catalyst. Furthermore, 1D model of ammonia port injection CI engine has been discussed. Results shows that ammonia can used to obtain the same output power like only diesel fuel. Also, the $\mathrm{CO}_{2}$ emission is reduced exponentially by using ammonia.

The utilised strategy of CFD modelling proved simple and reliable solution method. Step-by-step schematic of solution with cold flow calculation performed first and then performing heat exchange increased the stability of solution. Porous zone method allowed for great decrease of cells number that was necessary for proper meshing of the domain, but required experimental input and is simplification relying on negligible changes of viscosity and density of the fluid. Since that parameters changes, with relation to changing temperature in real world operation, so should change inverted permeability and inertial resistance parameters. That will be focus of future work.

The used modelling allows for parametric $\mathrm{NH}_{3}$-SCR optimisation. Solution is stable and physically possible. Calculations allowed to select points of stable flow where probes can be inserted to compare experimental and computed results for improved quality validation. Heat loses analysis gives a foundation for system redesign.

\section{Acknowledgements}

This work was funded by Norway and Poland contract (Contract NO. NOR/POLNOR/ACTIVATE/0046/2019-00) in ACTIVATE Project.

Further information: https://ammoniaengine.org

Authors also would like to thank D. Kurzydym, Z. Żmudka and A. Klimanek [13, 14] for providing their experimental data of SCR.

\section{Nomenclature}

a Experimental quadratic coefficient of pressure drop

b Experimental linear coefficient of pressure drop

BSFC brake specific fuel consumption

C Vibe function parameter $\mathrm{C}=6.9$

$\mathrm{C} 1$ single cylinder

$\mathrm{C}_{2}$ inertial resistance in porous zone

CI compression ignition

CFD Computational Fluid Dynamics

DI direct injection

E1 engine
ICE internal combustion engine

$\mathrm{m}$ shape parameter of Vibe function

MP Measurement point

SCR selective catalytic reduction

$\mathrm{S}$ body force (source term)

$v_{i} \quad$ velocity normal to the porous face in one specific direction mass fraction burned permeability of the medium

$\emptyset_{z} \quad$ initial and current time 
$\emptyset \quad$ angle between two Vibe functions

$\sigma_{g} \quad$ duration of combustion $\mu$

viscosity of mixture

\section{Bibliography}

[1] GRANNELL, S.M., ASSANIS, D.N., BOHAC, S.V. et al The fuel mix limits and efficiency of a stoichiometric, ammonia, and gasoline dual fuelled spark ignition engine. Journal of engineering for gas turbines and power. 2008, 130(4). https://doi.org/10.1115/1.2898837

[2] REITER, A.J., KONG, S.C. Combustion and emissions characteristics of compression-ignition engine using dual ammonia-diesel fuel. Fuel. 2011, 90(1), 87-97. https://doi.org/10.1016/j.fuel.2010.07.055

[3] REITER, A.J., KONG, S.C. Demonstration of compressionignition engine combustion using ammonia in reducing greenhouse gas emissions. Energy \& Fuels. 2008, 22(5), 2963-2971. https://doi.org/10.1021/ef800140f

[4] SALEK, F., BABAIE, M., SHAKERI, A. et al. Numerical study of engine performance and emissions for port injection of ammonia into a gasoline/ethanol dual-fuel spark ignition engine. Applied Sciences. 2021, 11(4), 1441. https://doi.org/10.3390/app11041441

[5] VALERA, A. et al. Review on ammonia as a potential fuel: from synthesis to economics. Energy Fuels. 2021, 35, 69647029. https://doi.org/10.1021/acs.energyfuels.0c03685

[6] NAKAJIMA, F., HAMADA, I. The state-of-the-art technology of $\mathrm{NO}_{\mathrm{x}}$ control. Catalysis Today. 1996, 29, 109-115. https://doi.org/10.1016/0920-5861(95)00288-X

[7] SOO-JIN, J., WOO-SEUNG, K. A numerical approach to investigate transient thermal and conversion characteristics of automotive catalytic converter, advanced converter concepts for emission control. SAE Technical Paper 980881. 1998. https://doi.org/10.4271/980881

[8] HUANG, H., CHEN, Y., Li, Z. et al. Analysis of deposit formation mechanism and structure optimization in ureaSCR system of diesel engine. Fuel. 2020, 265, 116941. https://doi.org/10.1016/j.fuel.2019.116941

[9] KOEBEL, M., ELSENER, M., KLEEMANN, M. UreaSCR: a promising technique to reduce $\mathrm{NO}_{\mathrm{x}}$ emissions from automotive diesel engines. Catalysis Today. 2000, 59(3-4), 335-345. https://doi.org/10.1016/S0920-5861(00)00299-6

[10] ROPPERTZ, A., FÜGER, S., KURETI, S. Investigation of urea-SCR at low temperatures. Topics in Catalysis. 2017, 60, 199-203. https://doi.org/10.1007/s11244-016-0597-8

\begin{abstract}
Kacper Kuta, MSc. - Faculty of Energy and Environmental Engineering, Silesian University of Technology.

e-mail: kacper.kuta@polsl.pl
\end{abstract}

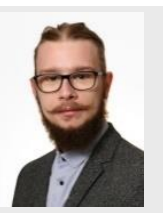

Prof. Grzegorz Przybyla, DSc., DEng. - Faculty of Energy and Environmental Engineering, Silesian University of Technology.

e-mail: grzegorz.przybyla@polsl.pl

Prof. Wojciech Adamczyk, DSc., DEng. - Faculty of Energy and Environmental Engineering, Silesian University of Technology.

e-mail: wojciech.adamczyk@polsl.pl

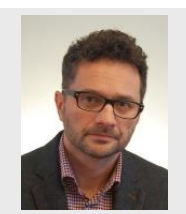

[11] DAMMA, D., ETTIREDDY P.R., REDDY, B.M. et al. A review of low temperature $\mathrm{NH}_{3}-\mathrm{SCR}$ for removal of $\mathrm{NO}_{\mathrm{x}}$. Catalysts. 2019, 9(4), 349. https://doi.org/10.3390/catal9040349

[12] DUMESIC, J.A., TOPSOE, N.-Y., CHEN, Y. et al. Kinetics of selective catalytic reduction of nitric oxide by ammonia over vanadia/titania. Journal of Catalysis. 1996, 163, 409417. https://doi.org/10.1006/jcat.1996.0342

[13] ZHU, Y., ZHOU, S., FENG, Y. et al. Influence of $\mathrm{NH}_{4} \mathrm{NO}_{3}$ formation on the $\mathrm{NO}_{\mathrm{x}}$ reduction pathways over vanadiumbased catalyst under diesel exhaust conditions. Russian Journal of Physical Chemistry A. 2018, 92, 1473-1480. https://doi.org/10.1134/S0036024418080319

[14] NOVA, I., CIARDELLI, C., TRONCONI, E. Unifying redox kinetics for standard and fast $\mathrm{NH}_{3}-\mathrm{SCR}$ over a $\mathrm{V}_{2} \mathrm{O}_{5^{-}}$ $\mathrm{WO}_{3} / \mathrm{TiO}_{2}$ catalyst. AIChE Journal. 2009, 55(6), 1514-1529. https://doi.org/10.1002/aic.11750

[15] NOVA, I. COLOMBO, M., TRONCONI, E. Kinetic modeling of dynamic aspects of the standard $\mathrm{NH}_{3}$-SCR reaction over $\mathrm{V}_{2} \mathrm{O}_{5}-\mathrm{WO}_{3} / \mathrm{TiO}_{2}$ and $\mathrm{Fe}$-zeolite commercial catalysts for the aftertreatment of diesel engines exhausts. Oil \& Gas Science and Technology - Revue de l IFP. 2011, 66(4), 681691. https://doi.org/10.2516/ogst/2011132

[16] YAO, J. ZHONG, Z., ZHU, L. Porous medium model in computational fluid dynamics simulation of a honeycombed SCR DeNOx catalyst. Chemical Engineering \& Technology. 2015, 38(2), 283-290. https://doi.org/10.1002/ceat.201400127

[17] KURZYDYM, D., KLIMANEK, A., ŻMUDKA, Z. Experimental and numerical analysis of flow through catalytic converters for original part and WALKER's replacement using reverse engineering and CFD. IOP Conferences Series: Materials Science and Engineering. 2018, 421, 042044. https://doi.org/10.1088/1757-899X/421/4/042044

[18] KURZYDYM, D., KLIMANEK, A., ŻMUDKA, Z. Experimental research and CFD analysis of flow parameters in a SCR system for the original part and WALKER's replacement. Combustion Engines. 2019, 179(4), 12-19. https://doi.org/10.19206/CE-2019-402

Ebrahim Nadimi, MSc. - Faculty of Energy and Environmental Engineering, Silesian University of Technology.

e-mail: enaimi@polsl.pl

Prof. Zbigniew Żmudka, DSc., DEng. - Faculty of Energy and Environmental Engineering, Silesian University of Technology. e-mail: zbigniew.zmudka@polsl.pl 